\title{
Performance and carbon turnover in fast- and slow-growing broilers submitted to cyclic heat stress and fed on high-protein diets
}

D.M.B. Campos, M. Macari, M.F. Fernadez-Alarcon, W.C.L. Nogueira, F.A. de SOUZA, F.H. HADA, R. LUNEDO \& J.C. Denadai

To cite this article: D.M.B. Campos, M. Macari, M.F. Fernadez-Alarcon, W.C.L. Nogueira, F.A. de SOUZA, F.H. HADA, R. LUNEDO \& J.C. Denadai (2016) Performance and carbon turnover in fast- and slow-growing broilers submitted to cyclic heat stress and fed on high-protein diets, British Poultry Science, 57:1, 84-92, DOI: 10.1080/00071668.2015.1115467

To link to this article: https://doi.org/10.1080/00071668.2015.1115467

Accepted author version posted online: 04

Dec 2015.

Published online: 29 Feb 2016

Submit your article to this journal $₫$

山 Article views: 199

View Crossmark data 5

Citing articles: 2 View citing articles $\sqsubset$ 


\title{
Performance and carbon turnover in fast- and slow-growing broilers submitted to cyclic heat stress and fed on high-protein diets
}

\author{
D.M.B. CAMPOS, M. MACARI, M.F. FERNADEZ-ALARCON, W.C.L. NOGUEIRA, \\ F.A. DE SOUZA, F.H. HADA, R. LUNEDO, AND J.C. DENADAI ${ }^{1}$ \\ Departamento de Morfologia e Fisiologia Animal, Universidade Estadual de São Paulo, Jaboticabal, Brasil, and \\ ${ }^{1}$ Departamento de Física e Biofísica, Instituto de Biociências, Universidade Estadual Paulista, Botucatu, Brasil
}

\begin{abstract}
Two experiments were conducted to test the hypothesis that when using similar protein/ amino acid diets and environment temperature conditions, the performance and carbon turnover in muscle and liver tissues, as measured by the incorporation of stable isotopes $\left({ }^{13} \mathrm{C} /{ }^{12} \mathrm{C}\right)$, must be different between fast-growing Cobb 500® and slow-growing Label Rouge broilers.

2. For both experiments (Cobb and Label Rouge), 21-d-old birds were distributed in a completely randomised, $3 \times 3$ factorial design; three environmental temperatures (cyclic heat stress ad libitum, $22^{\circ} \mathrm{C}$ ad libitum, and $22^{\circ} \mathrm{C}$ restricted) and three crude protein concentrations (189.1, 210 and $220 \mathrm{~g} / \mathrm{kg} \mathrm{CP}$ ) were used.

3. The Cobb $500 \AA$ had better performance with higher concentrations of crude protein. Cyclic heat stress (a temperature factor), negatively affected this genetic strain's performance. For the Label Rouge birds, the crude protein concentrations in the diet presented inconsistent results and cyclic heat stress did not affect the performance.

4. The carbon turnover rate was affected in the Cobb $500 ®$ strain, with a high protein content reducing carbon turnover in the evaluated tissues (liver and muscles). Feed intake had a greater impact on carbon turnover rates than cyclic heat stress. The Label Rouge birds were not affected by the evaluated factors, suggesting that genetic improvement has a leading role on tissue carbon turnover.

5. There is a genetic influence on carbon turnover in the liver and muscle tissues of broiler chickens. In addition, genetically fast-growing broilers are more susceptible to variations in diet composition and environmental temperature than less rapidly growing animals.
\end{abstract}

\section{INTRODUCTION}

Feed efficiency in broilers has increased markedly in recent decades. Havenstein et al. (2003a, $2003 b$ ) showed that $85-90 \%$ of this increased productivity is due to genetic improvement programmes. Performance improvement, especially in the development of muscle mass, is a function of advances in genetic potential. The greater protein mass in genetically improved chickens (broiler strains) is due to the balance between increased protein synthesis and degradation, i.e., turnover. These mechanisms of synthesis degradation are independent and have different influences and, with increased energy costs, they have become relevant efficiency factors (Doherty et al., 2009).

Broiler rearing in hot environments is the subject of much scientific debate. Heat stress reduces feed intake (FI) and consequently, the animal's performance. Thus, changes in the nutritional composition of feed, such as increased crude protein/amino acids and changing of the diet particle sizes, have been suggested for maintaining productivity in heat stress conditions (Temim et al., 2000a, 2000b; Gonzalez-Esquerra and Leeson, 2005; Faria Filho et al., 2007).

Incorporation of carbon or nitrogen in tissues has been investigated through the use of stable isotopes. This natural isotopic abundance has

Correspondence to: Marcos Macari, Departamento de Morfologia e Fisiologia Animal, Universidade Estadual de São Paulo, Jaboticabal, Via de Acesso Prof. Paulo Donato Castellane s/n 14884-900, Jaboticabal, São Paulo, Brasil. E-mail: macari@fcav.unesp.br

Accepted for publication 7 September 2015. 
been used by various authors to measure enrichment changes to the ratio of ${ }^{13} \mathrm{C} /{ }^{12} \mathrm{C}$ isotopes and infer turnover in different tissues (Martineau et al., 1985; Martins et al., 2012; Ducatti et al., 2014). Furthermore, Tieszen et al. (1983) showed that the most metabolically active tissues, such as blood and the liver, rapidly alter isotopic enrichment, and consequently have a higher turnover than less metabolically active tissues, such as skeletal muscle and bone. A better understanding of how carbon incorporates in the different tissues of fast- and slow-growing broilers may aid in the development of better nutritional programmes for mitigating heat stress.

This study tested the hypothesis that when using similar protein/amino acid diets and environmental temperature conditions, the performance and carbon turnover of muscle and liver tissues, as measured by the incorporation of stable isotopes $\left({ }^{13} \mathrm{C} /{ }^{12} \mathrm{C}\right)$, must be different between Cobb 500® (a fast-growing, genetically improved strain) and Label Rouge (slower growing, not genetically improved) broiler strains.

\section{MATERIALS AND METHODS}

\section{Birds and experimental design}

The birds were raised in three climate-controlled chambers, each $6.0 \mathrm{~m} \times 8.0 \mathrm{~m}$, with concrete floors. The side and top walls consisted of insulating material with 4 exhaust fans. The chambers were equipped with cooling systems and infrared lamps controlled by thermostats. Lighting was 24L:0D (15 lx), with an average relative humidity of $51 \pm 2 \%$.

Two experiments, one for each genetic group, were performed. Experiment I used Cobb $500 \AA$ broilers, a fast-growing genetic strain. This experiment was run from 21 to $45 \mathrm{~d}$ of age. Experiment II used Label Rouge naked-neck broilers, a slow-growing genetic group. Experiment II ran from 21 to $55 \mathrm{~d}$, because of the longer maturity rate for these birds. The birds in both experiments received the same diet (Table 1) until $21 \mathrm{~d}$ of age and were grown at the temperature recommended for Cobb $500 \AA$ broilers. At $21 \mathrm{~d}$, the birds were weighed and experimental units were composed with chickens of the same average weight.

A total of 720 male chickens were used for each experiment. The birds were distributed in a completely randomised, $3 \times 3$ factorial design; three environmental temperatures (cyclic heat stress ad libitum, $22^{\circ} \mathrm{C}$ ad libitum, and $22^{\circ} \mathrm{C}$ restricted) and three crude protein concentrations (189.1, 210 and $220 \mathrm{~g} / \mathrm{kg} \mathrm{CP})$. There were 9 treatments with 4 replicates of 20 birds each, totalling 36 experimental units in each experiment.

The birds in the cyclic heat stress treatment were subjected to an oscillating temperature scheme of $16 \mathrm{~h}$ at $22^{\circ} \mathrm{C}$ and $8 \mathrm{~h}$ at $32^{\circ} \mathrm{C}$. For the $22^{\circ} \mathrm{C}$ restricted treatment; the birds received the same amount of feed as consumed by the birds under the cyclic heat stress ad libitum treatment on the previous day. The pair-feeding schedule was used to separate the effects of temperature and FI on the studied variables.

This study was conducted in accordance with the ethical principles for animal experimentation adopted by the Brazilian College of Experimentation (COBEA) and with approval of the local Committee for Ethical Animal Use (CEUA), São Paulo State University (UNESP), Jaboticabal, SP, Brazil.

\section{Experimental diets}

For the first $21 \mathrm{~d}$ in both experiments, the birds were fed on the same diet based on photosynthetic cycle $\mathrm{C}_{3}$ plants. After $21 \mathrm{~d}$, they were fed on diets based on photosynthetic cycle $\mathrm{C}_{4}$ plants. This procedure standardised the isotopic values for the animals to differentiate it from the diet based on $\mathrm{C}_{4}$ plants. The food ingredients derived from plants of the photosynthetic cycles $\mathrm{C}_{3}$ and $\mathrm{C}_{4}$ have different isotopic values, approximately $14 \%$.

During photosynthetic assimilation, plants with the photosynthetic cycle $\mathrm{C}_{3}$ fix atmospheric $\mathrm{CO}_{2}$ by the Calvin-Benson cycle and have $\delta^{13} \mathrm{C}$ values between -22 and $-34 \%$. Plants with the $\mathrm{C}_{4}$ cycle fix $\mathrm{CO}_{2}$ through the Hatch-Slack cycle and have values between -9 and $-16 \%$. The negative sign indicates that the plants have lower concentrations of ${ }^{13} \mathrm{C}$ than the international standard. Therefore, $\mathrm{C}_{3}$ and $\mathrm{C}_{4}$ plants have different isotopic signatures $\left({ }^{13} \mathrm{C} /{ }^{12} \mathrm{C}\right)$ due to the fractionation that occurs during photosynthetic carbon fixation (Gannes et al., 1998). This natural isotopic ratio difference permits the formulation of diets with different isotopic patterns to be used as natural tracers.

The control diet for both experiments was formulated with nutritional levels suggested by Rostagno (2011). Diets with high protein contents (210 and $220 \mathrm{~g} / \mathrm{kg} \mathrm{CP}$ ) presented nutrient concentrations and metabolisable energy similar to the control diet (Table 1). However, in all experimental diets, the supplemented arginine is in excess of the amounts recommended. The arginine supplementation was designed to keep the lysine:arginine (LYS:ARG) relationship at 1.39.

\section{Performance}

The following performance indicators were obtained for the two periods from 21 to $45 \mathrm{~d}$ of age (Experiment $\mathrm{I}$ ) and 21 to $55 \mathrm{~d}$ of age (Experiment II): FI, weight gain (WG), feed conversion $(\mathrm{FC}=\mathrm{FI} / \mathrm{WG})$, protein intake $(\mathrm{CPI})$ and protein feed conversion $(\mathrm{PFC}=\mathrm{CPI} / \mathrm{WG})$. FI and $\mathrm{FC}$ 
Table 1. Diet composition $(\mathrm{g} / \mathrm{kg})$, calculated nutrient concentrations and values of the isotopic enrichment of the experimental diets

\begin{tabular}{|c|c|c|c|c|}
\hline \multirow[b]{2}{*}{ Ingredients $\mathrm{g} / \mathrm{kg}$} & \multirow[b]{2}{*}{$\begin{array}{l}\text { Starter } \\
(1-21 \mathrm{~d})\end{array}$} & \multicolumn{3}{|c|}{ Grower (22-45 d) } \\
\hline & & $\begin{array}{c}189.1 \\
\mathrm{CP}\end{array}$ & $\begin{array}{l}210 \\
\mathrm{CP}\end{array}$ & $\begin{array}{l}220 \\
\mathrm{CP}\end{array}$ \\
\hline Maize meal & - & 623.6 & 545.9 & 514.1 \\
\hline Rice, milled & 556.6 & - & - & - \\
\hline Soybean meal, $450 \mathrm{~g} / \mathrm{kg} \mathrm{CP}$ & 361.5 & 282.9 & 357.5 & 389.7 \\
\hline Soybean oil & 39.8 & 45.4 & 58.4 & 63.2 \\
\hline Limestone & 8.4 & 8.3 & 8.3 & 8.3 \\
\hline Dicalcium phosphate & 18.0 & 12.2 & 11.6 & 11.3 \\
\hline $\mathrm{NaCl}$ & 4.9 & 4.5 & 4.5 & 4.5 \\
\hline $\begin{array}{l}{ }^{1} \text { Vitamin \& mineral } \\
\text { supplement }\end{array}$ & 5.0 & - & - & - \\
\hline $\begin{array}{l}{ }^{2} \text { Vitamin \& mineral } \\
\text { supplement }\end{array}$ & - & 5.0 & 5.0 & 5.0 \\
\hline 1-Lysine $\mathrm{HCl}$ & 2.4 & 3.0 & 0.8 & 0.0 \\
\hline dl-methionine & 1.8 & 1.6 & 1 & 0.7 \\
\hline l-threonine & 1.4 & 1 & - & - \\
\hline L-arginine & - & 4.0 & 1.9 & 1.2 \\
\hline $\begin{array}{l}\text { Butylated hydroxytoluene } \\
\text { (antioxidant) }\end{array}$ & 0.1 & 0.1 & 0.1 & 0.1 \\
\hline Kaolin, inert & 0.1 & 8.4 & 5 & 2 \\
\hline $\begin{array}{l}\text { Experiment } \mathrm{I} \delta^{13} \mathrm{C}(\% o) \\
\quad(n=5)\end{array}$ & -28.58 & -19.22 & -19.57 & -22.61 \\
\hline $\begin{array}{l}\text { Experiment II } \delta^{13} \mathrm{C}(\% o), \\
\quad(n=5)\end{array}$ & -28.45 & -18.54 & -21.10 & -19.89 \\
\hline \multicolumn{5}{|c|}{ Calculated nutritional concentrations } \\
\hline $\mathrm{ME}, \mathrm{MJ} / \mathrm{kg}$ & 12.64 & 13.33 & 13.33 & 13.33 \\
\hline Crude protein, $\mathrm{g} / \mathrm{kg}$ & 216.0 & 189.1 & 210.0 & 220.0 \\
\hline Calcium, $\mathrm{g} / \mathrm{kg}$ & 8.7 & 7.0 & 7.0 & 7.0 \\
\hline Phosphorus available, $\mathrm{g} / \mathrm{kg}$ & 4.2 & 3.3 & 3.3 & 3.3 \\
\hline Sodium, $\mathrm{g} / \mathrm{kg}$ & 2.1 & 2.0 & 2.0 & 2.0 \\
\hline Lysine, $\mathrm{g} / \mathrm{kg}$ & 12.5 & 10.8 & 10.8 & 11.0 \\
\hline Methionine, $\mathrm{g} / \mathrm{kg}$ & 6.4 & 5.4 & 5.1 & 4.9 \\
\hline Methionine + cystine, $\mathrm{g} / \mathrm{kg}$ & 9.0 & 7.9 & 7.9 & 7.9 \\
\hline Threonine, $\mathrm{g} / \mathrm{kg}$ & 8.1 & 7.0 & 7.1 & 7.5 \\
\hline Tryptophan, g/kg & 2.6 & 2.0 & 2.3 & 2.5 \\
\hline Arginine, $\mathrm{g} / \mathrm{kg}$ & 14.4 & 15.0 & 15.1 & 15.3 \\
\hline Arginine:lysine & 1.15 & 1.39 & 1.40 & 1.39 \\
\hline Methionine:lysine & 0.51 & 0.50 & 0.47 & 0.45 \\
\hline
\end{tabular}

${ }^{1}$ Guaranteed concentrations per $\mathrm{kg}$ of product: nicotinic acid $6930 \mathrm{mg}$. biotin $32 \mathrm{mg}$; manganese $15252 \mathrm{mg}$; choline $120 \mathrm{mg}$; calcium pantothenate $1900 \mathrm{mg}$; retinyl acetate $420 \mathrm{mg}$; thiamine $356 \mathrm{mg}$; cyanocobalamin $2000 \mathrm{mcg}$; riboflavin $1920 \mathrm{mg}$; pyridoxine $693 \mathrm{mg}$; cholecalciferol $15 \mathrm{mg}$; $\alpha$ tocopherol $5000 \mathrm{mg}$; menadione $196 \mathrm{mg}$; copper $25000 \mathrm{mg}$; iodine $260 \mathrm{mg}$; selenium $54.6 \mathrm{mg}$; zinc $18250 \mathrm{mg}$; antioxidant $100 \mathrm{mg}$; coccidiostat $25000 \mathrm{mg}$; DL-methionine (minimum) $340 \mathrm{~g}$; growth and feed efficiency promoter $10000 \mathrm{mg}$.

${ }^{2}$ Guaranteed concentrations per $\mathrm{kg}$ of product: nicotinic acid $6930 \mathrm{mg}$; biotin $32 \mathrm{mg}$; choline $120 \mathrm{mg}$; manganese $15252 \mathrm{mg}$; calcium pantothenate $1900 \mathrm{mg}$; retinyl acetate $420 \mathrm{mg}$; thiamine $356 \mathrm{mg}$; cyanocobalamin 2000 mcg; riboflavin $1920 \mathrm{mg}$; pyridoxine $693 \mathrm{mg}$; cholecalciferol $15 \mathrm{mg}$; $\alpha$ tocopherol $5000 \mathrm{mg}$; menadione $196.5 \mathrm{mg}$; selenium $54.6 \mathrm{mg}$; copper 25 $000 \mathrm{mg}$; iodine $260 \mathrm{mg}$; zinc $18250 \mathrm{mg}$; antioxidant $100 \mathrm{mg}$; coccidiostat 22 $000 \mathrm{mg}$; DL-methionine (minimum) $270 \mathrm{~g}$; growth and feed efficiency promoter $10000 \mathrm{mg}$.

used the mortality date to calculate the number of adjusted birds (Sakomura and Rostagno, 2007).

\section{Incorporation of ${ }^{13} \mathrm{C}$ in muscle and liver tissues}

For the Cobb $500 \AA$ strain, 4 animals per treatment were killed on d 20, 21, 22, 23, 26, 30, 34, 40 and 45. Next, samples of the pectoralis major muscle, sartorius muscle and liver were taken. The same was done with 4 birds from the Label Rouge lineage on $\mathrm{d} 20$, 21, 22, 23, 26, 30, 34, 40, 45, 50 and 55. The samples were immediately placed in Falcon tubes, identified and frozen at $-20^{\circ} \mathrm{C}$ for isotopic analysis.

The isotopic analysis was carried out according to Zuanon et al. (2006). First, the samples were thawed and dried in a forced air oven (Marconi: Model MA 0351, Brazil) at $56^{\circ} \mathrm{C}$ for $48 \mathrm{~h}$. Before grinding, only liver samples were defatted in ethylic ether in a Soxhlet apparatus for $4 \mathrm{~h}$, because richlipid tissues are poor in ${ }^{13} \mathrm{C}$ as compared to low-lipid tissues (Tieszen et al., 1983). Next, all tissues and experimental diets were ground in a Spex cryogenic mill (Model 6750 freezer $/$ mill) at $-196^{\circ} \mathrm{C}$. All sample particles were ground finer than $60 \mu \mathrm{m}$. Determination of isotopic composition was performed on a Delta- $V$ mass spectrometer (Thermo Scientific) coupled with an Elemental analyser Flash 2000 Organic EA (Thermo Scientific). The results were expressed in notation $\delta^{13} \mathrm{C}$, in which the pattern adopted was the Peedee Belemnite (PDB), with the analysis error on the order of $0.2 \%$, according to the equation below.

$$
\delta^{13} \mathrm{C}_{(\text {sample }, \text { standard })}=\left[\left(R_{\text {sample }} / R_{\text {standard }}\right)-1\right] \cdot 10^{3}
$$

$\delta^{13} \mathrm{C}=$ enrichment of the ratio ${ }^{13} \mathrm{C} /{ }^{12} \mathrm{C}$ of the sample compared to standard PDB (\%o);

$R=$ isotope ratio $\left({ }^{13} \mathrm{C} /{ }^{12} \mathrm{C}\right)$ of the sample and standard, dimensionless.

The incorporation of ${ }^{13} \mathrm{C}$ into the tissues was measured using the Ducatti et al. (2002) model.

$$
\delta^{13} \mathrm{C}_{(t)}=\delta^{13} \mathrm{C}_{(\mathrm{f})}+\left[\delta^{13} \mathrm{C}_{(\mathrm{i})}-\delta^{13} \mathrm{C}_{(\mathrm{f})}\right] \mathrm{e}^{-k t}
$$

$\delta^{13} \mathrm{C}_{(t)}=$ isotopic enrichment of carbon in the desired time;

$\delta^{13} \mathrm{C}_{(\mathrm{i})}=$ isotopic enrichment in the initial tissue;

$\delta^{13} \mathrm{C}_{(\mathrm{f})}=$ isotopic enrichment of carbon at the final;

$k=$ is the carbon exchange constant $\left(\mathrm{d}^{-1}\right)$;

$t=$ unit of time $(\mathrm{d})$.

The half-life $(t=T)$ of ${ }^{13} \mathrm{C}$ in the tissues was measured using the following equation:

$$
T=\ln 2 / k
$$

$T=$ half-life time $(\mathrm{d})$;

ln = Napierian logarithm;

the exchange time $t(\mathrm{~d})$.

$$
t=\left(-\frac{1}{k}\right) \ln (1-F)
$$

$F=0.95$ (95\% of atoms exchanged). 


\section{Statistical analysis}

For performance variables, data were subjected to analysis of variance using the General Linear Model procedure (GLM) of SAS ${ }^{\circledR}$ software (SAS Institute, 2002) and in cases of statistically significant differences, the means were compared by Tukey test at 5\% probability. The incorporation of ${ }^{13} \mathrm{C}$ in bird tissues for the trial period was performed by exponential fit of the first order, as proposed by Ducatti et al. (2002), using Origin ${ }^{\circledR}$ 6.0 Professional (Microcal Software, 1999).

\section{RESULTS}

\section{Performance}

Fast-growing Cobb 500® broilers

FI and FC were affected by the diet's crude protein levels (CPL). Birds in the $220 \mathrm{CP}$ treatment had lower FI and FC than animals in other treatments. The animals grown at $22^{\circ} \mathrm{C}$ ad libitum had higher FI than animals raised in $22^{\circ} \mathrm{C}$ restricted as well as those under cyclic heat stress. Animals raised in cyclic heat stress had lower FC than animals raised in $22^{\circ} \mathrm{C}$ ad libitum and $22^{\circ} \mathrm{C}$ restricted (Table 2).

For WG, the CPL did not have a significant effect, but temperature did. Birds kept in the $22^{\circ} \mathrm{C}$ ad libitum environment showed higher results than $22^{\circ} \mathrm{C}$ restricted and cyclic heat stress (Table 2).

Protein intake was affected by the evaluated factors. For CPL, the lowest consumption was observed for the 189.1 CP treatment, the other two treatments did not differ. For temperature, the $22^{\circ} \mathrm{C}$ treatment ad libitum had the highest protein intake, followed by restricted $22^{\circ} \mathrm{C}$ and cyclic stress (Table 2).

Finally, PFC was affected by both the ration's CPL and the experimental temperatures. Under the CPL factor, the $220 \mathrm{CP}$ had the best conversion rate; the other treatments did not differ. For the temperature factors, the best $\mathrm{PFC}$ was observed for cyclic stress, followed by $22^{\circ} \mathrm{C}$ ad libitum and $22^{\circ} \mathrm{C}$ restricted (Table 2).

\section{Slow-growing label rouge broilers}

FI was affected by temperature and CPL (Table 3). Birds fed on 189.1 CP had higher FI under the $22^{\circ} \mathrm{C}$ ad libitum treatment. However, for the other protein concentrations, the temperature scheme did not affect FI $(P>0.05)$. For $22^{\circ} \mathrm{C} a d$ libitum, animals fed on $210 \mathrm{CP}$ showed lower FI when compared to $189.1 \mathrm{CP}$ and $220 \mathrm{CP}$.

WG was affected by both CPL and temperature. Treatments with $220 \mathrm{CP}$ and $210 \mathrm{CP}$ were different $(P<0.05)$; however, the $189.1 \mathrm{CP}$ treatment did not differ from the others. For temperature factors, the $22^{\circ} \mathrm{C}$ restricted treatment had the smallest WG $(P<0.05)$, and the cyclic heat stress treatment did not differ from $22^{\circ} \mathrm{C}$ ad libitum (Table 2).

Both temperature and CPL had a significant effect on FC (Table 2). Animals under treatment $210 \mathrm{CP}$ showed the best FC rates, followed by treatments 189.1 CP and 220 CP. For temperature factors, the best FC was found under cyclic heat stress, and treatments $22^{\circ} \mathrm{C}$ restricted and $22^{\circ} \mathrm{C}$ ad libitum did not differ significantly $(P>0.05)$.

Protein intake was also affected by both factors (CPL and temperature). Increased dietary protein content resulted in a gradual increase in protein intake. As for the temperature factor, the $22^{\circ} \mathrm{C}$ treatment ad libitum had the highest protein intake (Table 2).

The PFC was worse with the increased protein diet $(P<0.05)$. However, for the temperatures studied, the cyclic stress presented the best conversion. The $22^{\circ} \mathrm{C}$ restricted and $22^{\circ} \mathrm{C}$ ad libitum treatments did not differ (Table 2).

\section{Incorporation of ${ }^{13} \mathrm{C}$}

\section{Fast-growing Cobb 500® broilers}

The change in $\delta^{13} \mathrm{C}$ values, enrichment equations $\left(\delta^{13} \mathrm{C}\right)$ over time $(t)$ in $\mathrm{d}$ and determination coefficient for the liver, pectoralis major and sartorius muscles are shown in Figure 1 and is further illustrated in Figure 3. Table 4 contains the half-life values (d) from $21 \mathrm{~d}$ of age (date of the change in diet), and Table 5 contains the values of the exchange time (d) for $95 \%$ of the carbon atoms for the different tissues.

The liver showed the lowest half-life value (Table 4). The half-life values for the pectoralis major and sartorius muscle were similar for the different factors studied. For liver tissue and muscles, the birds of treatment 189.1 CP showed the lowest half-life in the temperature treatment $22^{\circ} \mathrm{C}$ ad libitum (0.8, 3.6 and 3.0), followed by cyclic heat stress $(1.2,4.7$ and 3.6$)$ and $22^{\circ} \mathrm{C}$ restricted (1.5, 4.9 and 4.2$)$.

For the different tissues and temperature schemes, the treatment with $220 \mathrm{CP}$ had the largest half-life values (Table 4).

The exchange time for $95 \%$ of the carbon atoms in the liver for treatment $22^{\circ} \mathrm{C}$ ad libitum with $220 \mathrm{CP}$ was $23.7 \mathrm{~d}$. For the pectoralis major, birds of $22^{\circ} \mathrm{C}$ ad libitum with $220 \mathrm{CP}$ and cyclic stress with $220 \mathrm{CP}$ had values of 26.3 and $28.6 \mathrm{~d}$, respectively. As for the sartorius muscle, birds raised in $22^{\circ} \mathrm{C}$ ad libitum with $220 \mathrm{CP}$ exchanged $95 \%$ of the carbon atoms in $27.9 \mathrm{~d}$. It should be noted that the Cobb 500® experiment period was $24 \mathrm{~d}$ (from d 21 to 45), and therefore, the exchange time for $95 \%$ of carbon atoms was 


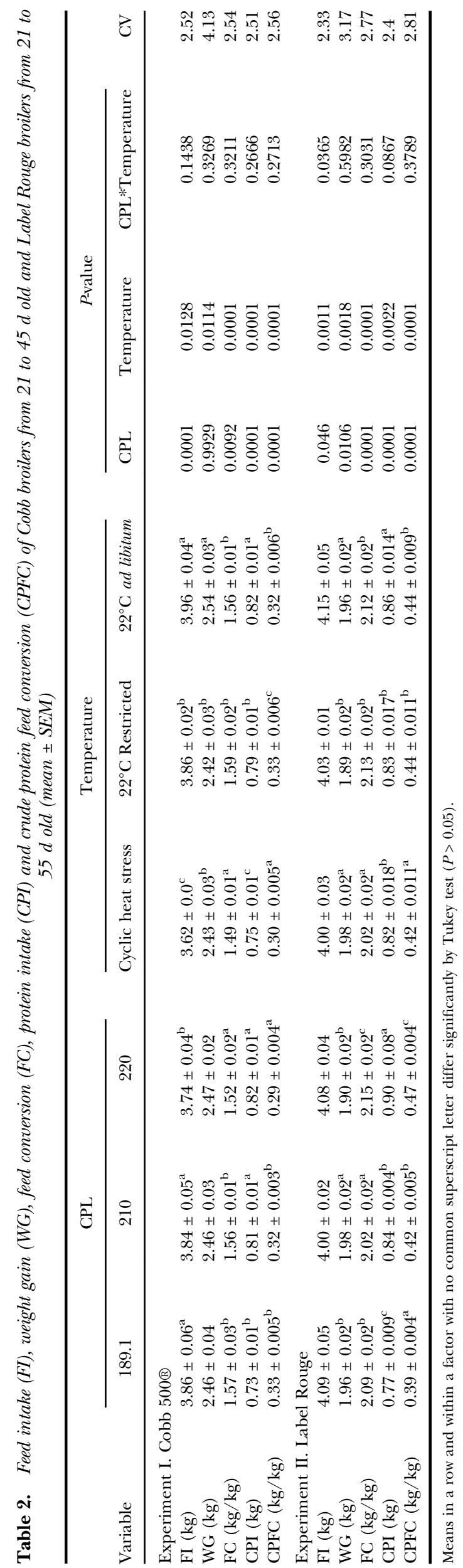


Table 3. Feed intake ( $\mathrm{kg})$ as affected by temperature and feeding different concentrations of dietary crude protein to Label Rouge birds from 21 to 55 d of age

\begin{tabular}{lccc}
\hline & \multicolumn{3}{c}{ Crude protein concentrations } \\
\cline { 2 - 4 } Temperature & $189.1 \mathrm{CP}$ & $210 \mathrm{CP}$ & $220 \mathrm{CP}$ \\
\hline Cyclic heat stress & $3.98 \pm 0.034^{\mathrm{aB}}$ & $3.99 \pm 0.051^{\mathrm{aA}}$ & $4.04 \pm 0.079^{\mathrm{aA}}$ \\
$22^{\circ} \mathrm{C}$ Restricted & $4.01 \pm 0.001^{\mathrm{aB}}$ & $3.99 \pm 0.003^{\mathrm{aA}}$ & $4.07 \pm 0.002^{\mathrm{aA}}$ \\
$22^{\circ} \mathrm{C}$ ad libitum & $4.29 \pm 0.06^{\mathrm{aA}}$ & $4.02 \pm 0.023^{\mathrm{bA}}$ & $4.15 \pm 0.078^{\mathrm{aA}}$ \\
\hline
\end{tabular}

Means in a column with no common uppercase superscript letter or in a row with no common lowercase superscript letter differ significantly by Tukey test $(P<0.05)$.

generally greater than the experimental period. This could have caused errors in the calculation of half-life values.

\section{Slow-growing label rouge broilers}

The change in $\delta^{13} \mathrm{C}$ values, enrichment equations $\left(\delta^{13} \mathrm{C}\right)$ over time $(t)$ in $\mathrm{d}$, and determination coefficient for liver, pectoralis major and sartorius muscles are shown in Figure 2 and further illustrated in Figure 3. Half-life values for the liver (Table 4) were lower than those for the pectoralis major and sartorius muscles for both environmental temperatures and diet protein concentrations. This was similar to the data for the Cobb $500 \AA$ birds. Also for the liver, the $210 \mathrm{CP}$ treatment in all temperatures showed higher half-life values when compared to other protein concentrations (Table 5). For the muscle tissue, the pectoralis major showed slightly higher half-life values than those of the sartorius (Table 4).

Unlike the genetically improved birds, the amount of time required to exchange $95 \%$ of the carbon atoms for all tissues evaluated was less than the experimental time period (Table 5).

\section{DISCUSSION}

The dietary CPL, as well as the feeding schemes in different environmental temperatures, affected performance and carbon incorporation into the liver and muscle tissue of the two genetic groups.

With regard to environmental stress, the genetically improved, fast-growing chickens (Cobb) had lower FI under cyclic heat stress and worse WG and lower crude protein consumption
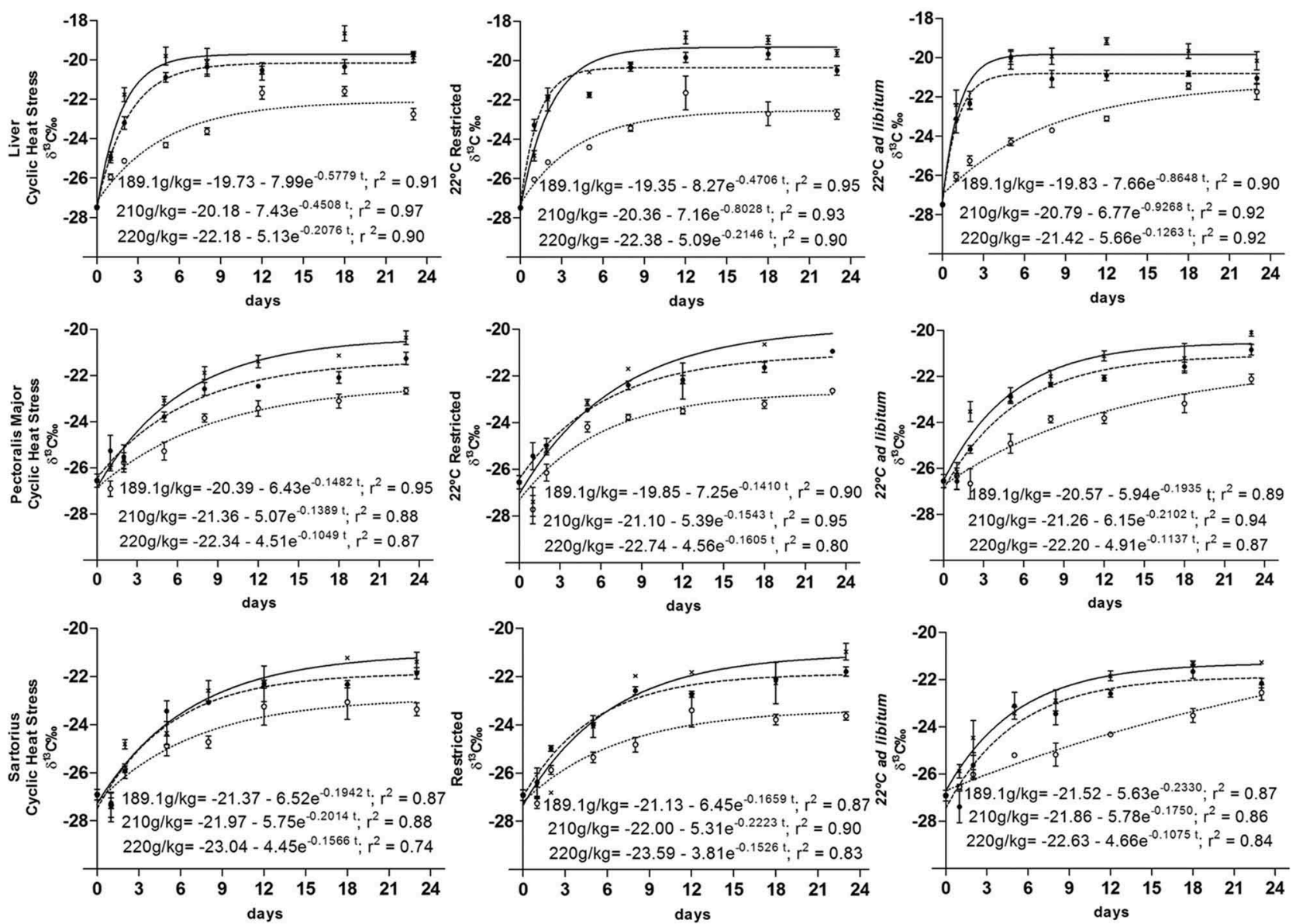

Figure 1. Stable carbon-isotope exponential models of liver, pectoralis major and sartorius muscles of Cobb broilers submitted to experimental treatments from 21 to $45 d$ of age, enrichment equations $\left(\delta^{13} C\right)$ over time $(t)$ in $d$ and determination coefficients. Data are means \pm SEM and sample sizes are $n=4$ for each point . 
Table 4. Half-life values (d) for liver tissue, pectoralis major and sartorius muscles for Cobb broilers 21 to 45 d of age and Label Rouge broilers 21 to $55 d$ of age

\begin{tabular}{|c|c|c|c|c|c|c|c|c|}
\hline \multirow[b]{3}{*}{ Tissue } & & \multirow[b]{3}{*}{ Temperature } & \multicolumn{6}{|c|}{ CPL } \\
\hline & & & \multicolumn{2}{|c|}{$189.1 \mathrm{CP}$} & \multicolumn{2}{|c|}{$210 \mathrm{CP}$} & \multicolumn{2}{|c|}{$220 \mathrm{CP}$} \\
\hline & & & Cobb $500 \AA$ & Label Rouge & Cobb 500® & Label Rouge & Cobb 500® & Label Rouge \\
\hline \multirow{3}{*}{\multicolumn{2}{|c|}{ Liver }} & $22^{\circ} \mathrm{C}$ ad libitum & 0.8 & 1.9 & 0.7 & 2.8 & 5.5 & 2.2 \\
\hline & & $22^{\circ} \mathrm{C}$ Restricted & 1.5 & 2.1 & 0.9 & 2.4 & 3.2 & 2.3 \\
\hline & & Cyclic heat stress & 1.2 & 1.9 & 1.5 & 2.4 & 3.3 & 1.6 \\
\hline \multirow[t]{6}{*}{ Muscle } & Pectoralis major & $22^{\circ} \mathrm{C}$ ad libitum & 3.6 & 7.7 & 3.3 & 6.9 & 6.1 & 6.1 \\
\hline & & $22^{\circ} \mathrm{C}$ Restricted & 4.9 & 6.4 & 4.5 & 6.4 & 4.3 & 6.7 \\
\hline & & Cyclic heat stress & 4.7 & 6.4 & 5.0 & 7.2 & 6.6 & 6.6 \\
\hline & Sartorius & $22^{\circ} \mathrm{C}$ ad libitum & 3.0 & 5.0 & 4.0 & 6.7 & 6.4 & 4.2 \\
\hline & & $22^{\circ} \mathrm{C}$ Restricted & 4.2 & 5.1 & 3.1 & 4.7 & 4.5 & 5.2 \\
\hline & & Cyclic heat stress & 3.6 & 5.0 & 3.4 & 6.1 & 4.4 & 6.0 \\
\hline
\end{tabular}

Table 5. Length of time (d) to replace $95 \%$ of the carbon atoms in the liver, pectoralis major and the sartorius muscles, for Cobb broilers from 21 to 45 d of age and Label Rouge from 21 to 55 d of age

\begin{tabular}{|c|c|c|c|c|c|c|c|c|}
\hline \multirow[b]{3}{*}{ Tissue } & & \multirow[b]{3}{*}{ Temperature } & \multicolumn{6}{|c|}{ CPL } \\
\hline & & & \multicolumn{2}{|c|}{$189.1 \mathrm{CP}$} & \multicolumn{2}{|c|}{$210 \mathrm{CP}$} & \multicolumn{2}{|c|}{$220 \mathrm{CP}$} \\
\hline & & & Cobb 500® & Label Rouge & Cobb $500 \AA$ & Label Rouge & Cobb $500 \AA$ & Label Rouge \\
\hline \multirow{3}{*}{\multicolumn{2}{|c|}{ Liver }} & $22^{\circ} \mathrm{C}$ ad libitum & 3.5 & 8.2 & 3.2 & 12.0 & $23.7 *$ & 9.7 \\
\hline & & $22^{\circ} \mathrm{C}$ Restricted & 6.4 & 9.1 & 3.7 & 10.3 & 14.0 & 9.9 \\
\hline & & Cyclic heat stress & 5.2 & 8.3 & 6.6 & 10.3 & 14.4 & 6.7 \\
\hline \multirow[t]{6}{*}{ Muscle } & Pectoralis major & $22^{\circ} \mathrm{C}$ ad libitum & 15.5 & 33.4 & 14.3 & 29.8 & $26.3 *$ & 26.2 \\
\hline & & $22^{\circ} \mathrm{C}$ Restricted & 21.2 & 27.6 & 19.4 & 27.9 & 18.7 & 28.9 \\
\hline & & Cyclic heat stress & 20.2 & 27.8 & 21.6 & 31.1 & $28.6^{*}$ & 28.6 \\
\hline & Sartorius & $22^{\circ} \mathrm{C}$ ad libitum & 12.9 & 21.6 & 17.1 & 28.9 & $27.9 *$ & 18.2 \\
\hline & & $22^{\circ} \mathrm{C}$ Restricted & 18.1 & 22.2 & 13.5 & 20.4 & 19.6 & 22.5 \\
\hline & & Cyclic heat stress & 15.4 & 21.7 & 14.9 & 26.3 & 19.1 & 26.0 \\
\hline
\end{tabular}

*Change time (d) in excess of the experimental period.

when compared to the animals grown under $22^{\circ} \mathrm{C}$ and fed ad libitum. This performance reduction was also found by Zhang et al. (2012) in Arbor Acres broilers (also fast growing), between 4 and 6 weeks of age and subjected to a constant heat stress of $34^{\circ} \mathrm{C}$, cyclic stress ( $6 \mathrm{~h}$ of daily stress at $\left.36^{\circ} \mathrm{C}\right)$, or thermoneutral temperature $\left(23^{\circ} \mathrm{C}\right)$. The cyclic and constant heat stress reduced WG 8.1 and $18.2 \%$, respectively, when compared to the thermoneutral temperature. In this study, there was a WG reduction of $4.33 \%$ in Cobb for cyclic heat stress treatments and $22^{\circ} \mathrm{C}$ restricted (isolating the temperature effect) when compared to the animals in thermoneutral conditions. These findings suggest that for genetically improved strains, the duration of the heat stress is an important factor for body weight reduction, as the longer the period of stress is, the greater the body weight loss.

The cyclic heat stress did not affect the performance of the slow-growing Label Rouge birds. These findings show higher heat resistance for these animals and corroborate data from other authors (Rosa et al., 2007; When et al., 2007).
When the amount of CPL was increased from 189.1 to $220 \mathrm{CP}$, a reduction in FI was observed in the Cobb line. This was accompanied, however, by increased protein intake, FC and PFC.

Increasing CPL has been suggested for heatstressed broilers, because it can compensate for the reduced intake of amino acids important for growth that results from the decreased feed consumption of heat stressed birds (GonzalezEsquerra and Leeson, 2005). The present findings show that diets with higher CPL did enable the animals to have a higher intake of amino acids, with better FC and better protein conversion. Thus, despite lower food intake and no difference in WG, our data suggest that metabolic efficiency was higher in these animals. Other research with high CPL and heat stress conditions has also showed improved performance for fast-growing broiler lines (Temim et al., 1999, 2000a, 2000b; Faria Filho et al., 2007).

For isotopic analysis, the half-life values $(T)$ of ${ }^{13} \mathrm{C}$ depend on, in part, tissue synthesis or degradation, and even re-synthesis of certain molecules. The average composition of the skeletal muscle and liver are 18.5 and $18.7 \%$ of protein, 3 and 

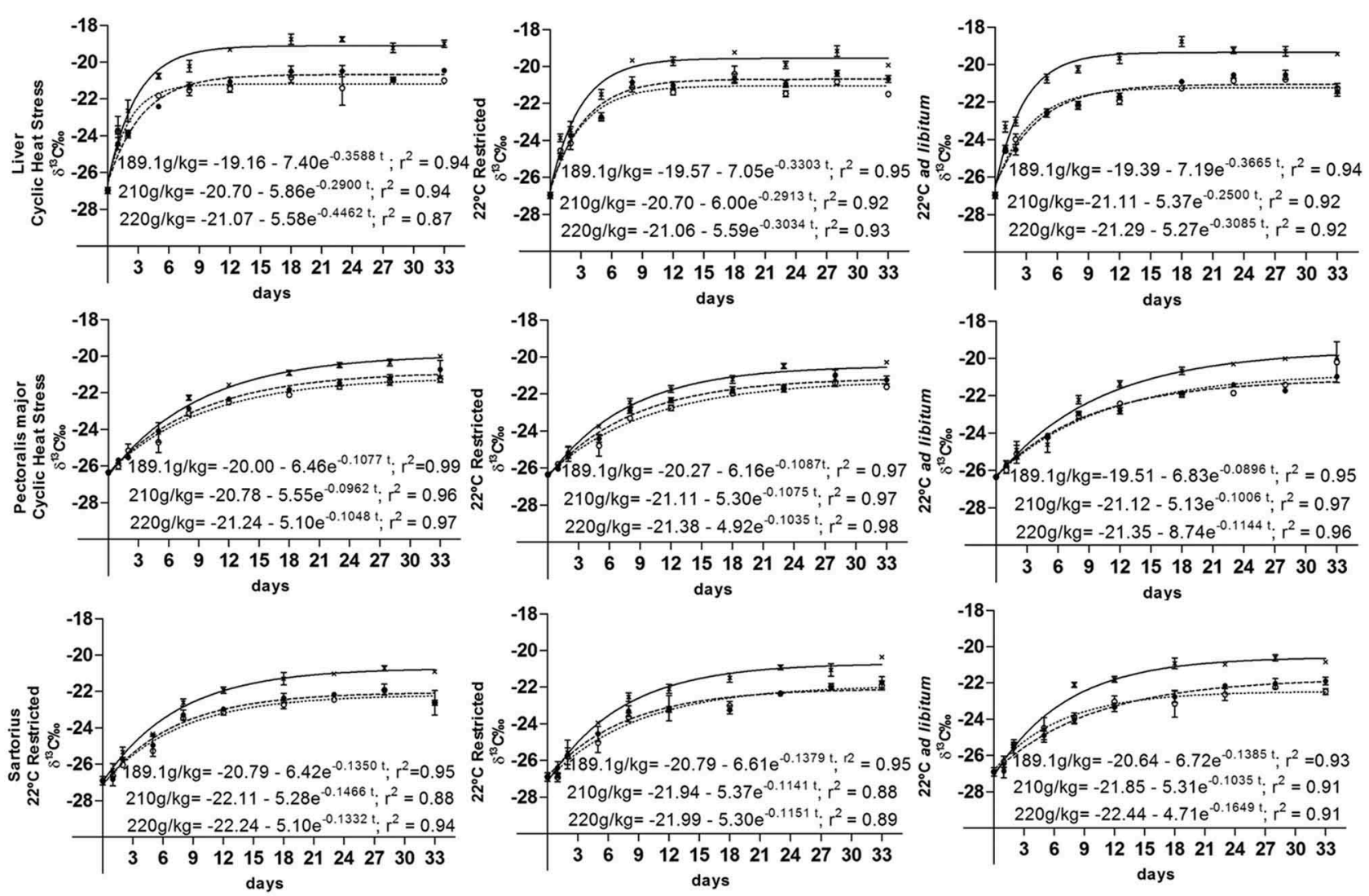

Figure 2. Stable carbon-isotope exponential models of liver, pectoralis major and sartorius muscles of Label Rouge birds submitted to experimental treatments from 21 to $55 d$ of age, enrichment equations $\left(\delta^{13} C\right)$ over time $(t)$ in d and determination coefficients. Data are means \pm SEM and sample sizes are $n=4$ for each point.

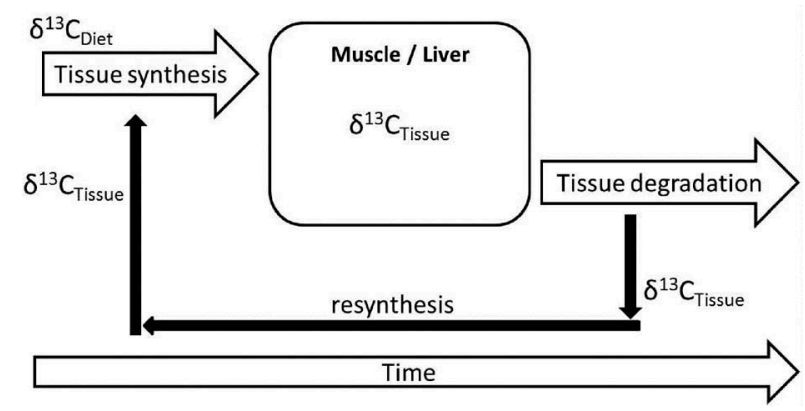

Figure 3. Illustration of isotopic enrichment factors of ${ }^{13} \mathrm{C}$ over time in evaluated tissues.

$15.4 \%$ fat and 0.8 and $8.2 \%$ carbohydrate, respectively. Thus, it could be assumed that changes in the ${ }^{13} \mathrm{C}$ incorporation rate reflect the changes in carbon turnover of the evaluated tissues (Cruz et al., 2005; Martins et al., 2012).

The half-life values for ${ }^{13} \mathrm{C}$ in the liver of the improved Cobb strain were 0.8 vs $1.5 \mathrm{~d}$ for broilers fed on $189.1 \mathrm{CP}$ raised at $22^{\circ} \mathrm{C}$ ad libitum and $22^{\circ} \mathrm{C}$ restricted, respectively (FI effect). For the temperature effect, the half-life of the liver's carbon showed little difference in chickens raised in cyclic heat stress vs $22^{\circ} \mathrm{C}$ ad libitum; 1.2 vs $1.5 \mathrm{~d}$, respectively. Thus, these findings reveal that temperature and FI determine different patterns of carbon turnover in the liver tissue of genetically improved chickens.

This same pattern was observed for the pectoralis major and sartorius muscles. However, for the non-genetically improved Label Rouge birds, this pattern was not observed. This suggests that genetic improvement has a leading role on tissue carbon turnover, probably due to the metabolic activity of these tissues (Tieszen et al., 1983), and FI has a greater impact on turnover rate than cyclic heat stress, but only in improved lines.

Studies on increasing CPL in hot-climate broiler diets suggest that this can improve performance; however, nothing has been described about carbon turnover in broilers fed on diets from $\mathrm{C}_{3}$ and $\mathrm{C}_{4}$ plants and the use of the stable carbon isotope technique. Our data show that when increasing the diet's CPL (220 CP), the carbon half-life in both liver and muscle is increased (Cobb strain only), on average 0.8$5.5 \mathrm{~d}$ for the liver tissue, 3.6-6.1 $\mathrm{d}$ for the pectoralis major muscle, and 3.0-6.4 d for sartorius muscle, for birds reared under $22^{\circ} \mathrm{C}$ and fed ad libitum. These data show that the carbon turnover in muscle and liver tissue of genetically improved poultry is reduced, suggesting a reduced metabolic activity. 
It has been suggested that the better performance of genetically improved broilers fed on high-protein diets and raised at high environmental temperatures is due to proteolysis reduction (Temim et al., 2000b). Our data revealed that carbon turnover was reduced when dietary protein was increased; giving evidence that tissues development is not only based on proteolysis, but also on synthesis and re-synthesis; however, based on the data of this study, it is not possible to quantify how much the carbon turnover in tissue is influenced by re-synthesis. Thus, further studies are needed to elucidate these issues.

In conclusion, the results support genetic influence on carbon turnover in the liver and muscle tissues of broiler chickens. Also, genetically improved broilers are more susceptible to variation in diet composition and environmental temperature than genetically non-improved animals.

\section{DISCLOSURE STATEMENT}

No potential conflict of interest was reported by the authors.

\section{FUNDING}

This study was supported by Fundação de Amparo à Pesquisa do Estado de São Paulo (FAPESP) [grant number 2011/05938-1].

\section{REFERENCES}

Cruz, V.C., Ducatti, C., Pezzato, A.C., Pinheiro, D.F., Sartori, J.R., Goncalves, J.C. \& Carrijo, A.S. (2005) Influence of diet on assimilation and turnover of $13 \mathrm{C}$ in the tissues of broiler chickens. British Poultry Science, 46: 382-389. doi:10.1080/ 0071660500126847

Doherty, M.K., Hammond, D.E., Clague, M.J., Gaskell, S.J. \& Beynon, R.J. (2009) Turnover of the human proteome: determination of protein intracellular stability by dynamic SILAC. Journal of Proteome Research, 8: 104-112. doi:10.1021/ pr800641v

Ducatti, C., Carrijo, A.S., Pezzato, A.C. \& Mancera, P.F.A. (2002) Modelo teórico e experimental da reciclagem do carbono-13 em tecidos de mamíferos e aves. Scientia Agricola, 59: 29-33. doi:10.1590/S0103-90162002000100003

Ducatti, C., Mituo, M.A.O., Denadai, J.C., Martins, M.B., Souza-Kruliski, C.R., Pelícia, V.C. \& Sartori, J.R. (2014) Turnover de carbono nos tecidos de frangos de corte em diferentes fases de crescimento. Ciência Rural, 44: 14721478. doi:10.1590/0103-8478cr20120962

Faria Filho, D.E., Campos, D.M.B., Alfonso-Torres, K.A., Vieira, B.S., Rosa, P.S., Vaz, A.M., Macari, M. \& Furlan, R. L. (2007) Protein levels for heat-exposed broilers: performance, nutrients digestibility and energy and protein metabolism. International Journal of Poultry Science, 6: 187-194. doi:10.3923/ijps.2007.187.194

Gannes, L.Z., DeL-Rio, C.M. \& Koch, P. (1998) Natural abundance variations in stable isotopes and their potential uses in animal physiological ecology. Comparative Biochemistry Physiology, 119 (3): 725-737. doi:10.1016/S1095-6433(98)01016-2
Gonzalez-Esquerra, R. \& Leeson, S. (2005) Effects of acute versus chronic heat stress on broiler response to dietary protein. Poultry Science, 84: 1562-1569. doi:10.1093/ps/ 84.10.1562

Havenstein, G.B., Ferket, P.R. \& Qureshi, M.A. (2003a) Carcass composition and yield of 1957 versus 2001 broilers when fed representative 1957 and 2001 broiler diets. Poultry Science, 82: 1509-1518. doi:10.1093/ps/82.10.1509

Havenstein, G.B., Ferket, P.R. \& QuReshi, M.A. (2003b) Growth, livability and feed conversion of 1957 versus 2001 broilers when fed representative 1957 and 2001 broiler diets. Poultry Science, 82: 1500-1508. doi:10.1093/ps/82.10.1500

Martineau, A., Lecavalier, L., Falardeau, P. \& Chiasson, J.L. (1985) Simultaneous determination of glucose turnover, alanine turnover, and gluconeogenesis in human using a double stable-isotope-labeled tracer infusion and gas chromatography-mass spectrometry analysis. Analytical Biochemistry, 151: 495-503. doi:10.1016/0003-2697(85)90210-6

Martins, M.B., Ducatti, C., Martins, C.L., Denadai, J.C., Natel, A.S., Souza-Kruliski, C.R. \& Sartori, M.M.P. (2012) Stable isotopes for determining carbon turnover in sheep feces and blood. Livestock Science, 149: 137-142. doi:10.1016/j. livsci.2012.07.004

Microcal Software Origin® 6.0 (1999) Professional. Origin Data Analysis and Technical Graphics. (Northampton, Microcal Software Inc.).

Rosa, P.S., Faria Filho, D.E., Dahlke, F., Vieira, B.S., Macari, M. \& FurLAN, R.L. (2007) Effect of energy intake on performance and carcass composition of broiler chickens from two different genetic groups. Revista Brasileira de Ciência Avicola/Brazilian Journal of Poultry Science, 9: 91-96.

Rostagno, H.S. (2011) Tabela brasileira para aves e suinos: composição de alimentos e exigências nutricionais. 3nd edn. (Viçosa, UFV, DZO).

Sakomura, N.K. \& Rostagno, H.S. (2007) Métodos de pesquisa em nutrição de monogástricos. (Jaboticabal, Funep).

SAS Institute (2002) SAS® User's Guide: Statistics (Cary, SAS Institute Inc.).

Temim, S., Chagneau, A.-M., Guillaumin, S., Michel, J., Peresson, R., Geraert, P.-A. \& Tesseraud, S. (1999) Effects of chronic heat exposure and protein intake on growth performance, nitrogen retention and muscle development in broiler chickens. Reproduction, Nutrition, Development, 39: 145-156. doi:10.1051/rnd:19990147

Temim, S., Chagneau, A.M., Guillaumin, S., Michel, J., Peresson, R. \& Tesseraud, S. (2000a) Does excess dietary protein improve growth performance and carcass characteristics in heat-exposed chickens?. Poultry Science, 79: 312-317. doi:10.1093/ps/79.3.312

Temim, S., Chagneau, A.M. \& Peresson, R. (2000b) Chronic heat exposure alters protein turnover of three different skeletal muscles in finishing broiler chickens fed 20 or 25\% protein diets. Journal of Nutrition, 130: 813-819.

Tieszen, L.L., Boutton, T.W., Tesdahl, K.G. \& Slade, N.A. (1983) Fractionation and turnover of stable carbon isotopes in animal tissues: implications for $\delta 13 \mathrm{C}$ analysis of diet. Oecologia, 57: 32-37. doi:10.1007/BF00379558

When, Q., Lu, J. \& Zhang, H. (2007) Effect of chronic heat exposure on fat deposition and meat quality in two genetic types of chicken. Poultry Science, 86: 1059-1064. doi:10.1093/ ps/86.6.1059

Zhang, Z.Y., Jia, G.Q., Zuo, J.J., Zhang, Y., Lei, J., Ren, L. \& FENG, D.Y. (2012) Effects of constant and cyclic heat stress on muscle metabolism and meat quality of broiler breast fillet and thigh meat. Poultry Science, 91: 2931-2937. doi:10.3382/ps.2012-02255

Zuanon, J.A., Pezzato, A.C., Pezzato, L.E., Passos, J.R., Barros, M.M. \& Ducatti, C. (2006) Muscle delta 13C chance in Nile Tilapia (Oreochromis niloticus) effects of growth and carbon turnover. Comparative Biochemistry and Physiology, 145: 101107. doi:10.1016/j.cbpb.2006.06.009 